\title{
Mammary leptin synthesis, milk leptin and their putative physiological roles
}

\author{
Muriel BonneT ${ }^{\mathrm{a}}$, Carole DelaVAUD ${ }^{\mathrm{a}}$, Karine LAUD ${ }^{\mathrm{b}}$, \\ Isabelle GOURDOU ${ }^{\mathrm{b}}$, Christine LEROUX ${ }^{\mathrm{a}}$, Jean DJIANE ${ }^{\mathrm{b}}$, \\ Yves CHILLIARD ${ }^{\mathrm{a} *}$ \\ ${ }^{a}$ Unité de Recherche sur les Herbivores, Équipe Tissu Adipeux et Lipides du Lait, INRA, \\ 63122 Saint-Genès-Champanelle, France \\ ${ }^{\mathrm{b}}$ Unité de Biologie Cellulaire et Moléculaire, INRA, \\ 78352 Jouy-en-Josas Cedex, France
}

\begin{abstract}
This paper reviews data on mammary leptin and leptin receptor gene expression as well as on blood and milk leptin levels during the pregnancy-lactation cycle in humans, rodents and ruminants, with the aim of better understanding milk leptin origin and functions. The few published papers report that leptin may be produced by different cell types in the mammary tissue, and may act as a paracrine factor on mammary epithelial cell proliferation, differentiation and/or apoptosis via adipose-epithelial and/or myoepithelial-epithelial cellular interactions. In addition to leptin synthesis, epithelial cells may transfer leptin from the blood, and these two mechanisms may account for the presence of leptin in the milk. The respective parts of these two processes remain to be determined, as well as the true milk leptin levels. Indeed, reported concentrations for milk leptin vary strongly according to species and mainly according to the milk fractions and the assay methods used. If leptin levels in milk (and specially colostrum) are found to be significant, this hormone could be involved in neonate physiology.
\end{abstract}

leptin / mammary tissue / milk

\section{INTRODUCTION}

Leptin is mainly but not exclusively produced and secreted by adipose tissue $[1,21$, 99], and functions as the afferent signal in a feedback loop regulating adipose tissue mass $[17,44]$. Leptin, via its receptors located in most peripheral tissues also appears to be implicated in the regulation of numerous other physiological aspects, including the

* Correspondence and reprints

E-mail: chilliar@clermont.inra.fr 
modulation of reproduction, the endocrine system, tissue metabolism, blood pressure, hematopoiesis, angiogenesis, brain and bone development, wound healing as well as cell differentiation and proliferation [1].

Leptin was assayed in human [16, 43, $56,74,81,91]$, rat [16], mouse [5], bovine [75] and porcine [27] milk. The presence of leptin in milk raises questions concerning the ability of the mammary epithelial cells to transfer leptin from the blood and/or to synthesize it, before its secretion. While one study has suggested the existence of leptin transfer from the blood to milk [16], probably involving leptin receptors expressed by the mammary gland $[48,78]$, other papers have shown mammary synthesis of leptin $[5,11,81]$. In order to gain a better insight and understanding of milk leptin origin and functions, this paper reviews the available data on mammary leptin and leptin receptor gene expressions, and on blood and milk leptin protein levels, according to pregnancy and lactation stages. The data are then discussed in relation to mammary gland development and functioning, and neonate physiology.

\section{EXPRESSION OF LEPTIN IN MAMMARY TISSUE}

The leptin gene is expressed in the mammary gland of lactating women [81], mice [5], ewes, cows and goats ([11], Fig. 1), or in normal breast epithelial (MCF-10A) and breast cancer (MCF-7, T47D, MDAMB-231) cell lines [67], as determined by RT-PCR and Northern-blot analysis. Leptin $\mathrm{mRNA}$ and protein are also produced by the bovine mammary epithelial cell line (MAC-T, [80]). Moreover, the 4.5-kb leptin transcript is similar in size to that expressed by adipose tissue, and the partial sequencing of cDNA corresponding to the coding sequence has revealed a complete homology between the mammary and the adipose tissue sequences in the human [81], murine [5], ovine, bovine and caprine species (Fig. 1).

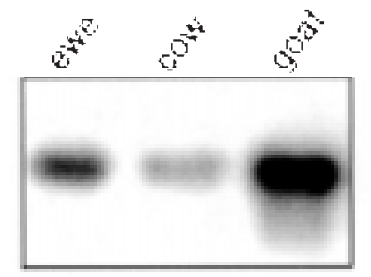

Figure 1. Expression of leptin by the lactating mammary gland of ruminants. Leptin mRNA was detected by Southern blot [82] analysis of reverse transcription-polymerase chain reaction (RT-PCR) products from mammary glands of a Préalpes du Sud ewe, an Holstein cow and an Alpine goat at days 48,100 and 30 of lactation, respectively. The leptin mRNA coding region (538 bp) was amplified after a reverse transcription step in the conditions described previously [9], using sense (5'-AGCCCATCCCGGGAAGGA-3') and antisense (5'-AGGCCTTCAAGGCTTCAGCA-3') primers replicating for 40 cycles $(1 \mathrm{~min}$ at $94{ }^{\circ} \mathrm{C}, 1 \mathrm{~min}$ at $62^{\circ} \mathrm{C}, 2 \mathrm{~min}$ at $72^{\circ} \mathrm{C}$ ). The specificity of PCR products was confirmed by direct sequencing of approximately $450 \mathrm{bp}$ and by Southern blot analysis. These ovine and bovine sequences revealed 100 or $99 \%$ identity with the published coding sequences from ovine (Acc no. U84247) or bovine (Acc no. U43943) adipose tissue, respectively. The goat mammary sequence shows 98 or $95 \%$ identity with these same published coding sequences, respectively. For Southern blot analysis, the probe corresponding to $350 \mathrm{bp}$ of the ovine leptin cDNA was used [24].

These last results suggest that there is a unique gene and a unique transcript encoding leptin, which is also expressed by the mammary tissue.

The quantitative analysis of leptin mRNA level (using RT-PCR) showed that leptin gene expression is regulated during gestation and lactation stages in ewes ([11], Fig. 2A) and mice ([5], Fig. 3). In these species, the leptin mRNA level is high in early pregnancy, decreases to lower levels from midpregnancy and remains low until the end of pregnancy and throughout lactation. Regarding the period around parturition in ewes, our study ([11], Fig. 2B) revealed a small 
Figure 2. The quantitative determination of leptin [11] and leptin receptor [48] mRNA levels in the ovine mammary gland throughout pregnancy and lactation. Leptin mRNA level was assayed both by semi quantitative (A) and real time (B) RT-PCR, and leptin receptor mRNA was assayed by the ribonuclease protection assay (C). (A) Leptin and cyclophilin mRNA were detected by Southern blot analysis of RT-PCR products amplified as described in the legend of Figure 1 and by Bonnet et al. [10], respectively. Analyses were performed from the mammary gland of an ewe at day 15, 80, 106, 112 and 141 of pregnancy and at day 3,48, and 70 of lactation. (B) Real time RT-PCR was performed using TaqMan methodology as described previously [9] from the mammary gland of ewes at day 15, 80, 106, 112 and 141 of pregnancy and at day 0 (30 minutes after parturition), and days 3 and 48 of lactation ( $n=3-4$ per stage). The leptin mRNA level was normalised to that of cyclophilin measured by real time RT-PCR [9]. Data are mean leptin/cyclophilin mRNA ratios and are expressed in arbitrary units (au). (C) The long and short forms of leptin receptor mRNA were quantified by the ribonuclease protection assay in the mammary gland of ewes at day 15 , $50,70,106,112$ and 141 of pregnancy and at day 3 , and 48 of lactation ( $n=3$ per stage). The leptin receptor mRNA level was normalised to that of glyceraldehyde-3-phosphate dehydrogenase. Data are mean leptin receptor/GAPDH mRNA ratios and are expressed in arbitrary units $(\mathrm{au})$.

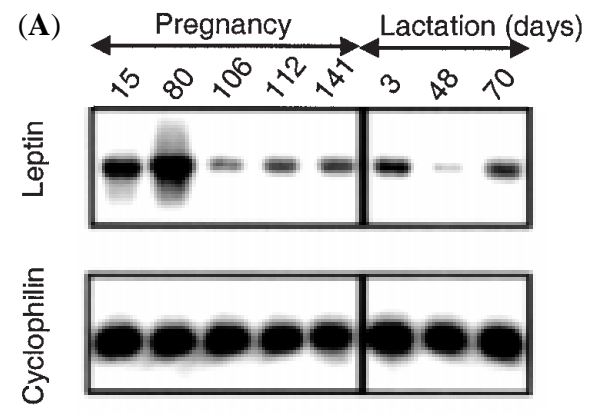

(B)

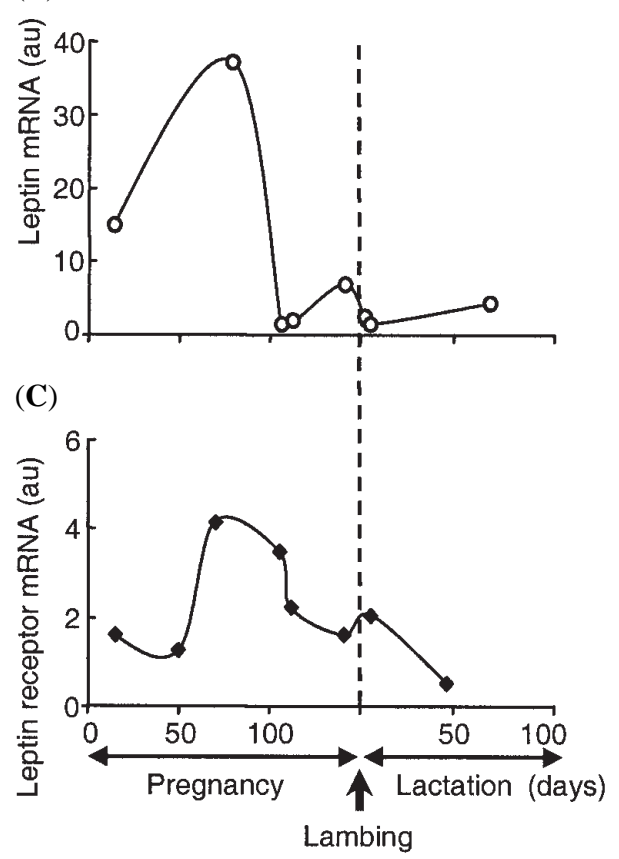

lactation stages in ewes [11]. Leptin protein was detected in mammary adipocytes during early stages of pregnancy, in epithelial cells and mainly on their apical membrane just before parturition, and in myoepithelial cells during lactation. Moreover, the presence of the leptin protein in secretory epithelial cells has been reported in breast tissue from lactating women [81]. These results may reflect leptin synthesis by adipocytes, epithelial and myoepithelial mammary cells, and/or leptin transfer between these cell types. 


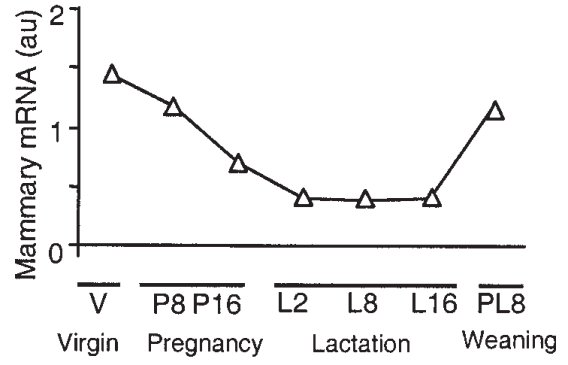

Figure 3. The evolution of leptin mRNA level in the mammary gland from virgin $(\mathrm{V})$, pregnant $(\mathrm{P})$, lactating (L) and post-lactating (PL) mice [5]. The leptin mRNA level was assayed by Southern blot analysis of RT-PCR amplicons produced using a specific set of primers and cDNA prepared from polyA+ RNA of the mammary gland of mice which were virgin, pregnant since 8 or 16 days, lactating since 2,8 or 16 days or post-lactating since 8 days $(n=4-5$ per stage). The leptin mRNA level was normalised to that of $\beta$-actin measured using the same procedure. Data are mean leptin/ $\beta$-actin mRNA ratios and are expressed in arbitrary units (au).

The regulatory mechanisms involved in the variations of leptin gene expression in mammary tissue have not been studied much. Nevertheless, it can be suggested that these mechanisms have two origins: the mammary cellular remodeling associated with pregnancy and the regulation of leptin gene expression. Indeed, it is noteworthy that the decrease in mammary leptin mRNA level around the first third of pregnancy observed in mice and ewes coincides with a strong decrease in mammary adipocyte numbers [26, 79]. In addition, the regulation of the expression of the leptin gene, probably via pregnancy- and lactationrelated hormones, may occur. This hypothesis is further supported by results reporting a 70 or $55 \%$ inhibition of leptin gene expression in the mouse mammary epithelial cell line COMMA-1D treated with prolactin or prolactin plus hydrocortisone [5].

\section{THE EXPRESSION \\ OF THE LEPTIN RECEPTOR IN MAMMARY TISSUE}

Leptin acts through membrane receptors that have strong sequence similarity with the class 1 cytokine receptor family [87]. Depending on the species, two to six leptin receptor isoforms $[2,86]$ have been identified and are encoded by alternative splicing of leptin receptor mRNA $[18,51,93]$. All these isoforms share an identical extracellular ligand-binding domain at the amino terminus but differ at the carboxy terminus by the length of the intracellular domain. Messenger RNAs encoding both short and long leptin receptor isoforms have been detected (by Southern blot analysis of RT-PCR products) in mammary tissue from pregnant or lactating ewes [48]. In contrast, the long form only was detected (by RT-PCR) in mammary tissue from a heifer two months after puberty, as well as in the MAC-T bovine mammary epithelial cell line [78]. Based on data from partial cDNA sequencing and the deduced amino acid sequence, the short and/ or long leptin receptors expressed in ovine and bovine mammary tissues share a high homology with the isoforms from the human brain and peripheral tissues $[48,78]$. In ewe mammary tissue, the short form is more expressed than the long form [48] as observed in most peripheral tissues from humans and rodents $[22,58,87]$.

Leptin receptor gene expression varies in the ovine mammary tissue during pregnancy and lactation ([48], Fig. 2C). Indeed, the mammary leptin receptor mRNA level, assayed by a ribonuclease protection assay using a probe that recognizes both the long and short forms, was higher at days 70 and 106 of pregnancy than at days 15, 50, 112, 141 of pregnancy or at days 3 or 48 of lactation. An in situ hybridization analysis confirmed this temporal variation of leptin receptor mRNA and showed that it was expressed only in the epithelial cells of the ovine mammary tissue [48]. The long leptin 
receptor isoform (as determined by immunohistochemistry) was also only observed in the epithelial cells from bovine mammary tissue [78].

The regulatory mechanisms of mammary leptin receptor gene expression during pregnancy and lactation have not been studied. However, as proposed above for the leptin gene, it can be hypothesized that pregnancyand lactation-related hormones are involved. In agreement with this hypothesis, the high expression of leptin receptor mRNAs at day 70 of pregnancy in the ewe [48] coincides with an increase in peripheral concentrations of estradiol [60], and with the changes in several other hormones such as progesterone, prolactin, placental lactogen, growth hormone [20].

\section{MILK LEPTIN LEVEL}

The leptin protein has been identified in the colostrum of pigs [27] and cows (C. Delavaud, M. Bonnet, Y. Chilliard, unpublished results) as well as in milk of humans [16, 43, 74, 81, 91], rat [16], mice [5], pigs [27], cows [75] and goats (C. Delavaud, M. Bonnet, Y. Chilliard, unpublished results). In human milk, leptin is present in a monomeric form [16].

Leptin concentrations in milk have been assayed mainly by radioimmunoassay. The data reported in Table I show strong variations in milk leptin concentrations according to the species, the period of lactation and mainly according to the milk fractions and the sample treatments used (Tab. I). Indeed,

Table I. Milk leptin concentration in different species.

\begin{tabular}{|c|c|c|c|c|}
\hline Species & $\begin{array}{c}\text { Stage } \\
\text { of lactation (d) }\end{array}$ & $\begin{array}{l}\text { Milk fraction } \\
\text { and treatments }\end{array}$ & $\begin{array}{l}\text { Assay } \\
\text { techniques }\end{array}$ & $\begin{array}{l}\text { leptin concentration } \\
\left(\mathrm{ng} \cdot \mathrm{mL}^{-1}\right)\end{array}$ \\
\hline Human [16] & N.R. & Skim milk & RIA $^{1}$ & $1.3 \pm 0.02$ \\
\hline Human [43] & $\begin{array}{l}\text { N.R. } \\
\text { N.R. }\end{array}$ & $\begin{array}{l}\text { Sonicated whole milk } \\
\text { Skim milk }\end{array}$ & $\begin{array}{l}\text { RIA }^{1} \\
\text { RIA }^{1}\end{array}$ & $\begin{array}{r}10.1 \pm 2.6 \\
1.5 \pm 0.9\end{array}$ \\
\hline Human [81] & $\begin{array}{l}\text { N.R. } \\
\text { N.R. }\end{array}$ & $\begin{array}{l}\text { Sonicated whole milk } \\
\text { Sonicated skim milk }\end{array}$ & $\begin{array}{l}\text { RIA }^{1} \\
\text { RIA }^{1}\end{array}$ & $\begin{array}{c}73.2 \pm 13.8 \\
1.1 \pm 0.1\end{array}$ \\
\hline Human [91] & N.R. & Whole milk & RIA $^{1}$ & $3.4 \pm 1.0$ \\
\hline Human [56] & $\begin{array}{l}60-120 \\
60-120\end{array}$ & $\begin{array}{l}\text { Whole milk } \\
\text { Skim milk }\end{array}$ & $\begin{array}{l}\text { RIA }^{1} \\
\text { RIA }^{1}\end{array}$ & $\begin{array}{c}32.7 \pm 14.1 \\
0.2 \pm 0.1\end{array}$ \\
\hline Human [74] & $7-28$ & Whole milk with lipid hydrolysis & RIA $^{1}$ & $5.2 \pm 5.0$ \\
\hline Mouse [5] & $\begin{array}{l}2-19 \\
2-19\end{array}$ & $\begin{array}{l}\text { Whole milk } \\
\text { Skim milk }\end{array}$ & $\begin{array}{l}\text { Sandwich Elisa } \\
\text { Sandwich Elisa }\end{array}$ & $\begin{array}{l}15 \pm 6 \\
1.5 \pm 0.5\end{array}$ \\
\hline Pig [27] & $\begin{array}{l}1-22 \\
1-22\end{array}$ & $\begin{array}{l}\text { Sonicated whole milk } \\
\text { Skim milk }\end{array}$ & $\begin{array}{l}\text { RIA }^{2} \\
\text { RIA }^{2}\end{array}$ & $\begin{array}{l}36 \pm 6 \\
18 \pm 4\end{array}$ \\
\hline Cow [75] & 94-190 & Sonicated whole milk & RIA $^{2}$ & $4.4 \pm 1.8$ \\
\hline $\mathrm{Cow}^{4}$ & 1 & Ultracentrifugated milk & $\mathrm{RIA}^{3}$ & 30 \\
\hline Goat $^{4}$ & $\begin{array}{l}270-300 \\
270-300 \\
270-300\end{array}$ & $\begin{array}{l}\text { Whole milk } \\
\text { Sonicated whole milk } \\
\text { Skim milk }\end{array}$ & $\begin{array}{l}\text { RIA }^{3} \\
\text { RIA }^{3} \\
\text { RIA }^{3}\end{array}$ & $\begin{array}{l}7.8 \pm 0.6 \\
7.6 \pm 0.5 \\
5.0 \pm 0.0\end{array}$ \\
\hline
\end{tabular}

Data are mean \pm SEM. N.R., not reported. ${ }^{1}$ Linco Human radioimmunoassay kit. ${ }^{2}$ Linco Multispecies radioimmunoassay kit. ${ }^{3}$ Specific radioimmunoassay for ruminants [23]. ${ }^{4}$ C. Delavaud, M. Bonnet and Y. Chilliard, unpublished results. 
in most of the species studied, leptin concentration was higher ( 2 to 66 fold) in whole milk than in skim milk. However, the significance of these results remains controversial because they may indicate that leptin is linked to the milk fat globules, as shown by immunohistochemical analysis in human milk [81], and/or could result from an artefact induced by an interference between milk fat and the radioimmunoassays used. Such an interference has been well documented by Lönnerdal and Havel [56], who showed that the addition of Intralipid into human skim milk results in abnormally high "leptin" concentrations.

Regarding the influence of the lactation stage, leptin concentration seems to be higher in colostrum than in post-colostral milk of pigs [27] and cows (C. Delavaud, M. Bonnet, Y. Chilliard, unpublished results). In mouse whole milk, leptin concentration was high at day 2 of lactation, decreased by about $50 \%$ at days 8, 12 and 16 and increased at day 19 to a level comparable to that observed at day 2 of lactation ([5], Fig. 4). Since skim milk leptin remains low whatever the lactation stage (Fig. 4), it could be hypothesized that either milk leptin is bound to fat globules and/or that lactational changes in milk fat content yield artifactual changes in the apparent leptin concentrations measured in whole milk samples. In contrast, no decrease in leptin concentrations after farrowing was observed in pig whole milk, but

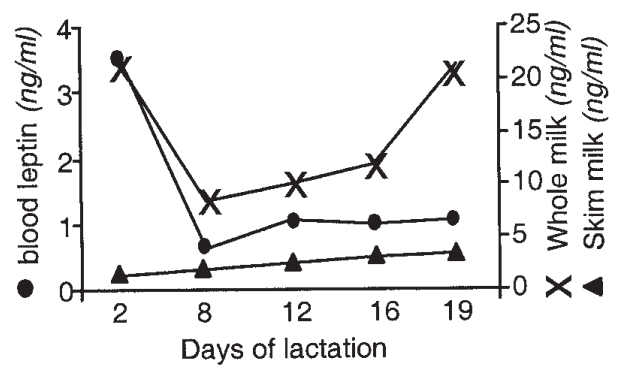

Figure 4. Leptin concentration in whole and skim milk, and in blood of lactating mice [5]. Leptin was assayed by sandwich Elisa. a decrease was observed in skim milk [27]. The available results thus suggest a variation in milk leptin level throughout lactation, particularly when considering the results obtained from pig skim milk.

The meaning of the published results on milk leptin concentrations in the different animal species remains, however, to be specified. There is a need for validation of milk leptin assay methods, including the linearity of the response to the milk volume used, and the possible interference between milk fat and assay methods. This would allow the true leptin concentrations in whole milk to be determined. Like Lönnerdal and Havel [56] in human milk, we observed that sonication did not modify the concentration of leptin in goat whole milk (C. Delavaud, M. Bonnet, Y. Chilliard, unpublished results). Assuming that both the interference by milk triglycerides and the masking of leptin inside the fat globule do not allow an accurate milk leptin titration, the lipid hydrolysis method recently proposed by Resto et al. [74] should improve milk titration better than milk sonication $[43,81]$.

\section{BLOOD LEPTIN DURING PREGNANCY AND LACTATION}

Leptin, produced mainly by adipose tissue, is present in nanomolar concentrations in the systemic circulation; its level is regulated by a variety of factors, particularly body fatness, feeding level, energy balance and the endocrine system $[17,21,30]$. These factors may partly explain the variations in maternal blood leptin occurring during the pregnancy-lactation cycle. Such variations could be taken into account to support or not the putative implication of circulating leptin in mammary epithelial cell development and function, via mammary leptin receptors.

The blood level of leptin increases towards two-thirds of pregnancy and dramatically decreases to pre-pregnancy 
levels around parturition in humans [14, 33, $39,53,61]$, baboons [37], rodents [5, 13, $19,31,38,47,89,96]$ and ewes [25]. This general profile of variation differs by the amplitude of variation according to the species and nutrition (Fig. 5). For example, a tendency towards an increase in circulating leptin until two-thirds of pregnancy was also observed in a particular model of adolescent ewes, however, nutrition rather than pregnancy stage modified leptinemia [88]. Blood leptin is also highly sensitive to the nutritional status in the late pregnant cow [42]. Regarding late pregnancy more specifically (Fig. 5), levels of blood leptin declined prior to parturition in rodents [5, 19, 38, 47], human [33, 35], ovine [25] and bovine [8, $42,46,55]$, but not in baboon [37] species.

The increase in blood leptin towards twothirds of pregnancy could result from three different mechanisms according to the species. An increased leptin synthesis by specific adipose tissues was reported in the pregnant rat [47], mouse [89], baboon [69] and ewe [25], but not in women. However, a positive correlation between either prepregnancy $[33,39,85]$ or pregnancy [50] body mass index and leptinemia, supports the contribution of adipose depots to the circulating leptin during pregnancy in women. Synthesis of leptin by the placenta has been described in women $[36,61]$ and baboons [37] and to a lower extent in rats [4, 47] and mice $[40,41,89]$. In agreement with the leptin-producing role for the placenta in humans, the leptin gene has a placentaspecific upstream enhancer [7] and its

Figure 5. Blood leptin concentration throughout pregnancy and lactation in the rat [19], mouse [5], baboon [37], woman [33], ewe [25] and cow [42]. Blood leptin were assayed using a commercial RIA kit in the rat and baboon, a commercial sandwich Elisa kit in the mouse and woman, and a specific RIA assay described by Ehrhardt et al. [25] and Delavaud et al. [23] in the ewe and cow, respectively. $\dagger$ or $*$, significantly different when compared to the non-pregnant or postpartum stage, respectively.

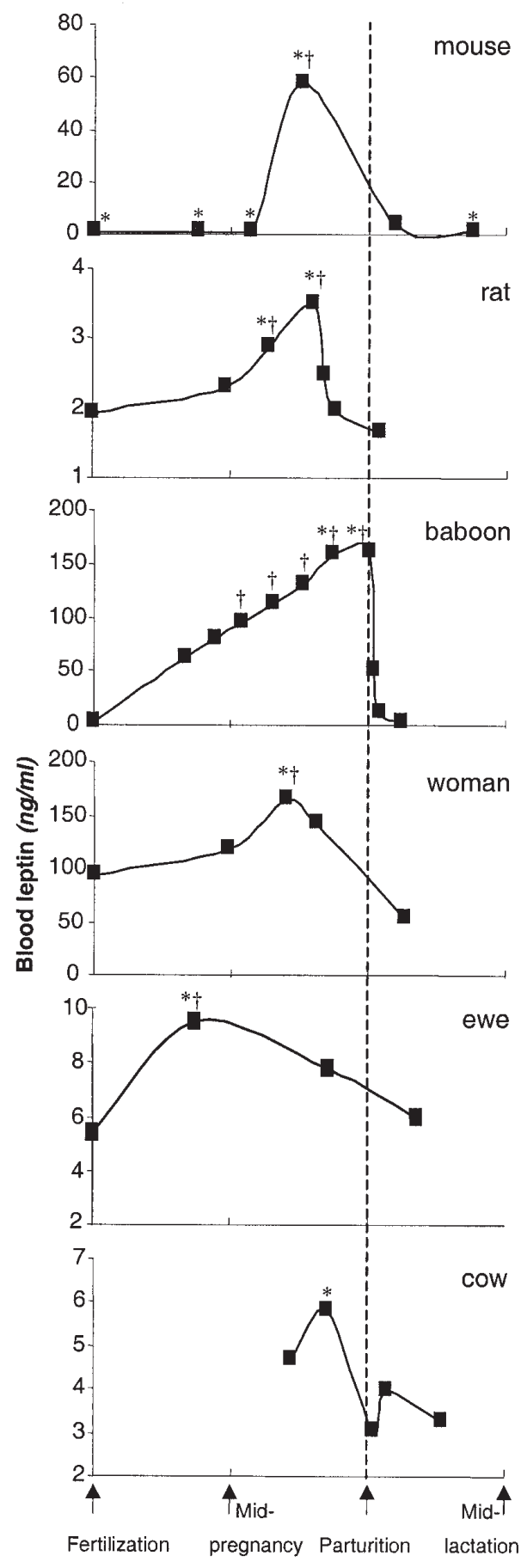


expression is highest during the first trimester of pregnancy [36]. Finally, in the pregnant mouse, the striking leptin rise has been explained by the reduced clearance of leptin due to its binding with a soluble leptin receptor (the shorter form) produced by the placenta [31]. Such a large increase in bound circulating leptin observed in the mouse during pregnancy [31] does not occur in humans since the level of the soluble receptor decreases between 20 and 30 weeks of pregnancy $[53,95]$. The relative contributions of adipose, placental and bound leptin levels to blood leptin variations probably differ across species, which may partly explain the differences observed between the species towards the end of pregnancy (Fig. 5)

\section{LEPTIN SECRETION AND EFFECTS DURING PREGNANCY AND LACTATION}

Altogether, data on blood and mammary leptin as well as on the presence of the long and short forms of the leptin receptor mRNA and/or protein in the mammary tissue suggest that leptin may play a direct role in mammary parenchyma development and function (Fig. 6) and may act on neonate physiology via milk.

\subsection{During pregnancy: mammogenesis}

Mammogenesis results from the proliferation and differentiation of secretory epithelial cells induced by various mediators. The increases in blood leptin level (see Sect. 5), as well as in leptin and leptin receptor gene expressions during the first half of pregnancy (see Sects. 2 and 3), are concomitant with the initiation of the proliferation of mammary epithelial cells, which suggests that both blood and/or mammary leptin, via leptin receptors, could exert endocrine, paracrine and/or autocrine control over mammogenesis (Fig. 7). This hypothesis is further supported by reports describing leptin as a cytokine able to inhibit or

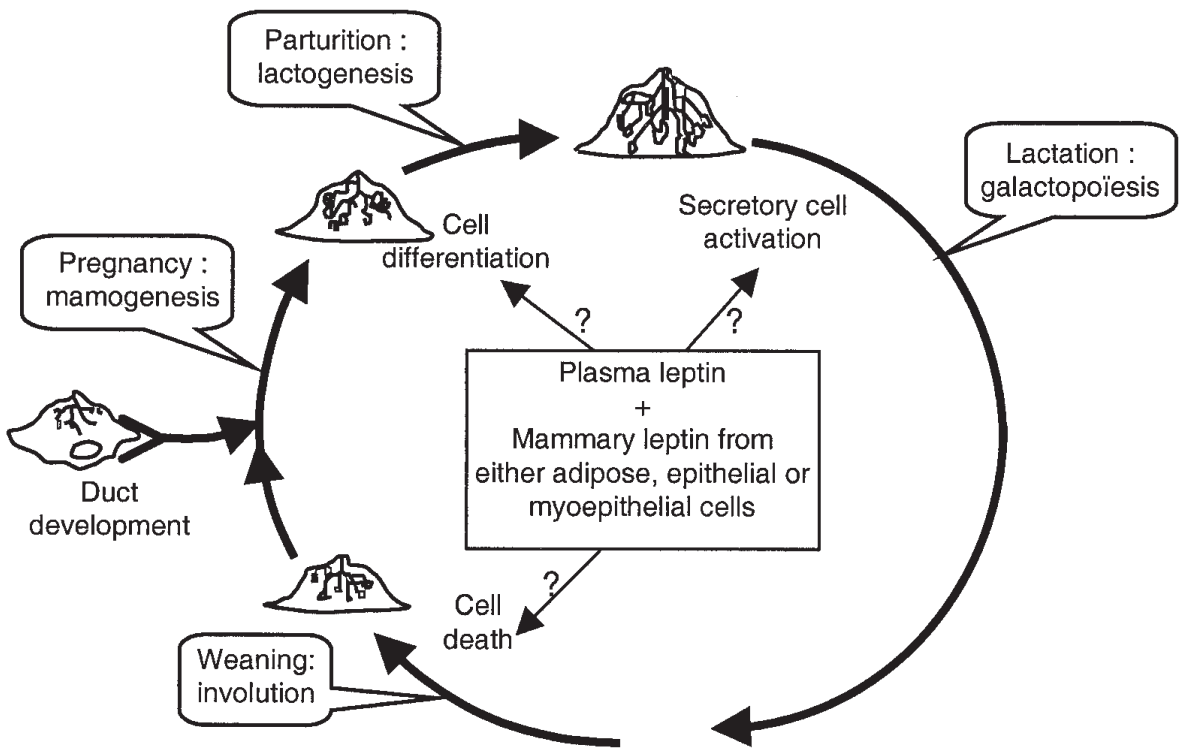

Figure 6. Leptin as a potential endocrine and/or paracrine signal involved in mammary epithelial cell growth and function. 
stimulate the proliferation of cultured bovine mammary MAC-T cells [77] or the human breast cancer cell line T47D [49], respectively. However, leptin has no effect on undifferentiated mammary cells originating from prepubertal heifers [73]. Further studies are needed to clarify the putative role of leptin on mammary epithelial cell proliferation and/or differentiation as well as its possible interaction with other mediators. Indeed, during pregnancy, mammary epithelial cell growth and development are highly dependent upon steroids and protein hormones derived from the ovaries, placenta, pituitary gland [59] and body adipose depots [90]. Moreover, in vivo and in vitro studies indicate that these hormonal effects are largely indirect, and mediated by growth factors synthesized by mammary adipocytes $[52,76,97]$. It is tempting to hypothesize that mammary leptin could be one of these hormone-inducible proteins synthesized by mammary fat cells (Fig. 7). Indeed, the strong mammary leptin gene expression observed at near mid-gestation in the ewe and mouse, occurs simultaneously with the start of the increase in blood concentrations of estradiol and other hormones [20, 29, 60].
In addition, the strong expression of the mammary leptin receptor at mid-gestation [48] suggests that blood leptin could reinforce the action of mammary leptin (which is less expressed from this pregnancy stage) and/or be involved in a feedback loop regulating mammary leptin synthesis, via leptin receptors (Fig. 7). However, although leptin receptors have been shown in human and rodent body adipocytes $[22,58]$ they remain to be demonstrated in mammary adipocytes. The relative contributions of mammary- and blood-derived leptins to mammogenesis remain to be established in different species, since their pregnancyrelated blood levels are very different (see Sect. 5 and Fig. 5).

\subsection{Around parturition: lactogenesis, colostrum secretion and neonate physiology}

At the end of pregnancy, mammary adipose tissue has completely regressed and leptin synthesis still occurs in the mammary tissue from the ewe [11] and mouse [5]. Moreover, the leptin protein is localized in

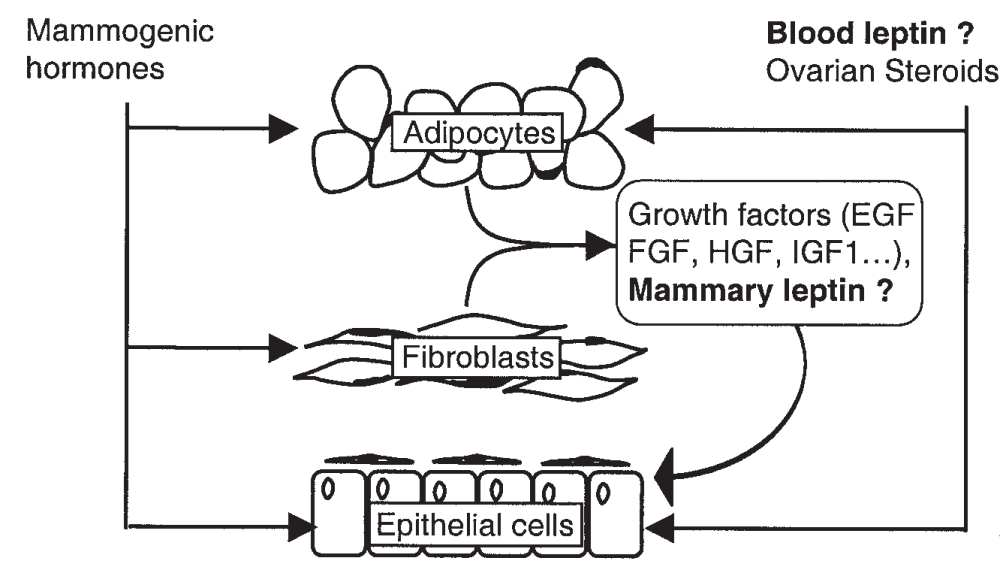

Figure 7. Leptin as a potential endocrine and/or paracrine signal involved in mammogenesis. Mammary leptin could be a steroid-inducible protein synthesized by mammary fat cells involved in epithelial cell proliferation and/or differentiation. In addition, blood leptin could reinforce the action of the mammary and/or be implied in a feedback loop regulating mammary leptin synthesis, via leptin receptors. 
secretory epithelial cells of the ovine mammary gland [11]. A production by epithelial cells is likely since a possible transfer of blood leptin would be very low due to the sharp decreases in the leptin receptor gene expression by the epithelial cells (see Sect. 3 and Fig. 2b) as well as in blood leptin levels (see Sect. 5 and Fig. 5). However, although probably low, a transfer of blood leptin to the epithelial cells (and then to the milk) exists, as shown by Casabiell et al. [16] in the lactating rat. The respective proportions of transfer and local production remain to be determined, but could explain the accumulation of the leptin protein on the apical membrane of epithelial cells [11] and its subsequent secretion in colostrum, as observed in mice [5], pigs [27] and cows (C. Delavaud, M. Bonnet and Y. Chilliard, unpublished results).

Colostral leptin may play a role in neonate physiology if (i) colostral-leptin is secreted in sufficient amounts, (ii) leptin is still biologically active after its absorption, and (iii) the endogenous leptin of the young is limiting. Although these topics remain to be studied, it can be suggested that leptin may act on neonate physiology before and after its digestive absorption (Fig. 8).

Before its absorption, leptin may modulate gastro-intestinal functions of the neonate. This hypothesis is supported by observations made in adult humans and rodents, where leptin, via the leptin receptor localized in gastric [12] or intestinal [15, $58,64]$ mucosa, could be involved in the control of meal size in co-operation with cholecystokinine, in the cytoprotection of gastric mucosa, in gut inflammatory processes and in the secretion of gastric hormones such as gastrin and somatostatin [54], in the proliferation of intestinal cells $[3,34]$ and in the transport of nutrients $[15,64,70]$.

After its absorption, if leptin is proven to remain biologically active, it could be further involved in neonate physiology (Fig. 8). Highly efficient absorption has been reported in 9 day-old rats [16] and 20 hourold pigs [94], but the biological activity of leptin has not been tested. This absorption may involve the vacuolized immature

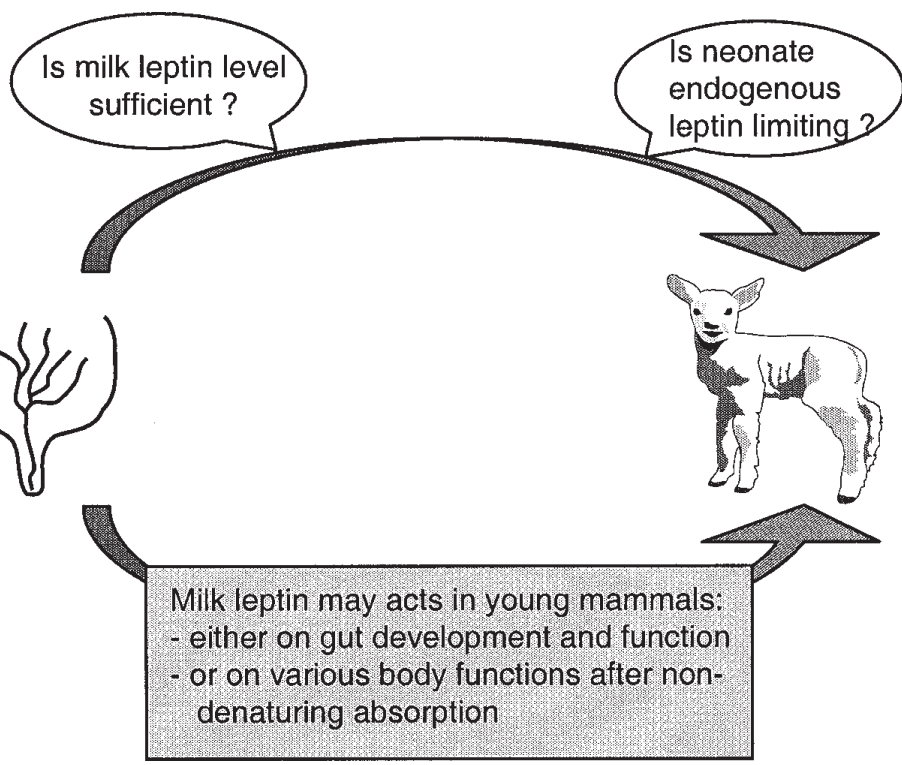

Figure 8. Putative effects of milk leptin on neonate physiology in mammals. 
Figure 9. Leptin as a potential endocrine and/or paracrine signal involved in galactopoeisis. During lactation, mammary leptin could be produced by myoepithelial cells, and may act, via epithelial cell leptin receptor, on epithelial cell proliferation and/or apoptosis. In addition, the plasma leptin could reinforce the action of mammary leptin.

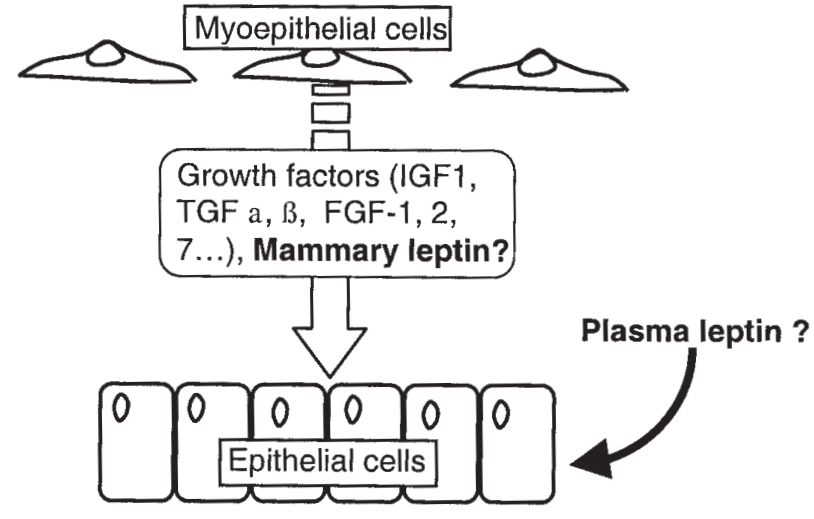

enterocytes which are permeable to macromolecules, as reported for other colostral proteins [6] and/or the transport by short leptin receptor isoforms, whose expression has been shown in human and rodent small intestines [15, 58, 64]. Once absorbed, a role for leptin in neonate immunity could be hypothesized in view of the results obtained in transgenic mice models such as $o b / o b$ and $d b / d b$ treated or not by leptin as well as in normal rodents and humans, that showed that leptin modulates cytokine production and the thymus size, the activation of monocytes/macrophages, the proliferation/apoptosis of $\mathrm{T}$ lymphocytes and the T helper (Th)1/(Th)2 balance [28, 57, 62]. Likewise, leptin induces the in vitro production of cytokines by blood mononuclear cells isolated from dairy cows [71]. In addition, milk leptin may be able to modify thermogenesis, post-natal changes in food intake, growth and development of neonates, as observed in studies on leptin-infused rodent and ovine neonates $[63,65,66,83$, $84,92,98]$.

\subsection{During lactation: galactopoiesis}

Throughout lactation, galactopoiesis is dependent on the maintenance of alveolar structures, which is partly modulated by growth factors such as IGF-1, TGF-alpha and beta, FGF-1, 2, 7 that are mainly synthesised by myoepithelial cells $[32,60,72]$. Leptin has been found in the ovine mammary myoepithelial cells [11]. A local production rather than a transfer of epithelial- or blood-derived leptin is suggested by the lack of leptin receptor expression by myoepithelial cells [48]. Hence, it can be hypothesised that myoepithelial leptin, acting through an epithelial cell leptin receptor, could participate in the control of epithelial cell proliferation or apoptosis (Fig. 9) as observed for $\mathrm{T}$ lymphocytes [45] and $\beta$-cell [68] apoptosis. In addition, the leptin receptor expressed by secretory epithelial cells may also contribute to the transfer of blood or myoepithelial leptin to the milk.

\section{CONCLUSION}

From the low number of studies performed to analyse mammary leptin and leptin receptor gene expression, it could be suggested that leptin is produced by different cell types of the mammary gland, and could act as a paracrine factor on mammary cell proliferation, differentiation and apoptosis via adipose-epithelial and myoepithelialepithelial cellular interactions. Besides synthesizing leptin, secretory epithelial cells may transfer leptin from the blood, and these two mechanisms may account for the 
presence of leptin in milk. The respective part of these two processes remains to be clarified, as well as the true levels of milk leptin. This hormone may be involved in neonate physiology via the milk. The roles of leptin in mammary tissue development and neonate physiology remain speculative and require more investigations. These topics are particularly important for a better understanding of the mechanisms for the known effects of nutritional factors and body fatness on peripubertal mammogenesis, and also when considering the long-term effects of neonatal nutrition on the subsequent health and development of young mammals.

\section{REFERENCES}

[1] Ahima R.S., Flier J.S., Adipose tissue as an endocrine organ, Trends Endocrinol. Metab. 11 (2000) 327-332.

[2] Ahima R.S., Flier J.S., Leptin, Annu. Rev. Physiol. 62 (2000) 413-437.

[3] Alavi K., Schwartz M., Prasad R., Leptin: a new growth factor for the small intestine, Surg. Forum L.I., 2000, p. 527.

[4] Amico J.A., Thomas A., Crowley R.S., Burmeister L.A., Concentrations of leptin in the serum of pregnant, lactating, and cycling rats and of leptin messenger ribonucleic acid in rat placental tissue, Life Sci. 63 (1998) 1387-1395.

[5] Aoki N., Kawamura M., Matsuda T., Lactationdependent down regulation of leptin production in mouse mammary gland, Biochim. Biophys. Acta. 1427 (1999) 298-306.

[6] Berthon P., Tanneau G., Salmon H., Immune factors of mammary secretions, in: Martinet J., Houdebine L.M., Head H.H. (Ed.), Biology of lactation, INRA Publ., Paris, 1999, pp. 453-480.

[7] Bi S., Gavrilova O., Gong D.W., Mason M.M. Reitman M., Identification of a placental enhancer for the human leptin gene, J. Biol. Chem. 272 (1997) 30583-30588.

[8] Block S.S., Butler W.R., Ehrhardt R.A., Bell A.W., Van Amburgh M.E., Boisclair Y.R., Decreased concentration of plasma leptin in periparturient dairy cows is caused by negative energy balance, J. Endocrinol. 171 (2001) 339-348.

[9] Bonnet M., Leroux C., Faulconnier Y., Hocquette J.F., Bocquier F., Martin P., Chilliard Y., Lipoprotein lipase activity and mRNA are up-regulated by refeeding in adipose tissue and cardiac muscle of sheep, J. Nutr. 130 (2000) 749-756.
[10] Bonnet M., Leroux C., Chilliard Y., Martin P. A fluorescent reverse transcription-polymerase chain reaction assay to quantify the lipoprotein lipase messenger RNA, Mol. Cell. Probes 15 (2001) 187-194.

[11] Bonnet M., Gourdou I., Leroux C., Chilliard Y., Djiane J., Leptin expression in the ovine mammary gland: putative sequential involvement of adipose, epithelial and myoepithelial cells during pregnancy and lactation, J. Anim. Sci. 80 (2002) 723-728.

[12] Breidert M., Miehlke S., Glasow A., Orban Z., Stolte M., Ehninger G., Bayerdorffer E., Nettesheim O., Halm U., Haidan A., Bornstein S.R., Leptin and its receptor in normal human gastric mucosa and in Helicobacter pyloriassociated gastritis, Scand. J. Gastroenterol. 34 (1999) 954-961.

[13] Brogan R.S., Mitchell S.E., Trayhurn P., Smith M.S., Suppression of leptin during lactation: contribution of the suckling stimulus versus milk production, Endocrinology 140 (1999) 2621-2627.

[14] Butte N.F., Hopkinson J.M., Nicolson M.A., Leptin in human reproduction: serum leptin levels in pregnant and lactating women, J. Clin. Endocrinol. Metab. 82 (1997) 585-589.

[15] Buyse M., Berlioz F., Guilmeau S., Tsocas A., Voisin T., Peranzi G., Laburthe M.C., Lewin M.J.M., Roze C., Bado A., Intestinal epithelial cells express leptin receptors that modulate the oligopeptide transporter pept-1, Gastroenterology 118 (2000) Abstract no. 3119.

[16] Casabiell X., Pineiro V., Tome M.A., Peino R., Dieguez C., Casanueva F.F., Presence of leptin in colostrum and/or breast milk from lactating mothers: a potential role in the regulation of neonatal food intake, J. Clin. Endocrinol. Metab. 82 (1997) 4270-4273.

[17] Casanueva F.F., Dieguez C., Neuroendocrine regulation and actions of leptin, Front. Neuroendocrinol. 20 (1999) 317-363.

[18] Chen H., Charlat O., Tartaglia L.A., Woolf E.A., Weng X., Ellis S.J., Lakey N.D., Culpepper J., Moore K.J., Breitbart R.E., Duyk G.M., Tepper R.I., Morgenstern J.P., Evidence that the diabetes gene encodes the leptin receptor: identification of a mutation in the leptin receptor gene in db/db mice, Cell 84 (1996) 491-495.

[19] Chien E.K., Hara M., Rouard M., Yano H., Phillippe M., Polonsky K.S., Bell G.I., Increase in serum leptin and uterine leptin receptor messenger RNA levels during pregnancy in rats, Biochem. Biophys. Res. Commun. 237 (1997) 476-480.

[20] Chilliard Y., Bibliographic review: quantitative variations and metabolism of lipids in adipose tissue and liver during the gestation-lactation cycle. 2. In the ewe and the cow, Reprod. Nutr. Dev. 27 (1987) 327-398. 
[21] Chilliard Y., Bonnet M., Delavaud C., Faulconnie Y., Leroux C., Djiane J., Bocquier F., Review: leptin in ruminants. Gene expression in adipose tissue and mammary gland, and regulation of plasma concentration, Domest. Anim. Endocrinol. 21 (2001) 271-295.

[22] De Matteis R., Cinti S., Ultrastructural immunolocalization of leptin receptor in mouse brain, Neuroendocrinology 68 (1998) 412-419.

[23] Delavaud C., Bocquier F., Chilliard Y., Keisler D.H., Gertler A., Kann G., Plasma leptin determination in ruminants: effect of nutritional status and body fatness on plasma leptin concentration assessed by a specific RIA in sheep J. Endocrinol. 165 (2000) 519-526.

[24] Dyer C.J., Simmons J.M., Matteri R.L., Keisler D.H., cDNA cloning and tissue-specific gene expression of ovine leptin, NPY-Y1 receptor, and NPY-Y2 receptor, Domest. Anim. Endocrinol. 14 (1997) 295-303.

[25] Ehrhardt R.A., Slepetis R.M., Bell A.W., Boisclair Y.R., Maternal leptin is elevated during pregnancy in sheep, Domest. Anim. Endocrinol. 21 (2001) 85-96.

[26] Elias J.J., Pitelka D.R., Armstrong R.C., Changes in fat cell morphology during lactation in the mouse, Anat. Rec. 177 (1973) 533-547.

[27] Estienne M.J., Harper A.F., Barb C.R., Azain M.J., Concentrations of leptin in serum and milk collected from lactating sows differing in body condition, Domest. Anim. Endocrinol. 19 (2000) 275-280.

[28] Fantuzzi G., Faggioni R., Leptin in the regulation of immunity, inflammation, and hematopoiesis, J. Leukoc. Biol. 68 (2000) 437-446.

[29] Finn C.A., Martin L., Hormone secretion during early pregnancy in the mouse, J. Endocrinol. 45 (1969) 57-65.

[30] Friedman J.M., Halaas J.L., Leptin and the regulation of body weight in mammals, Nature 395 (1998) 763-770.

[31] Gavrilova O., Barr V., Marcus-Samuels B., Reitman M., Hyperleptinemia of pregnancy associated with the appearance of a circulating form of the leptin receptor, J. Biol. Chem. 272 (1997) 30546-30551.

[32] Gomm J.J., Browne P.J., Coope R.C., Bansal G.S., Yiangou C., Johnston C.L., Mason R., Coombes R.C., A paracrine role for myoepithelial cell-derived FGF2 in the normal human breast, Exp. Cell Res. 234 (1997) 165-173.

[33] Hardie L., Trayhurn P., Abramovich D., Fowler P., Circulating leptin in women: a longitudinal study in the menstrual cycle and during pregnancy, Clin. Endocrinol. (Oxf) 47 (1997) 101-106.

[34] Hardwick J.C.H., Van Den Brink G.R., Offerhaus G.J., Van Deventer S.J.H., Peppelenbosch M.P., Leptin is a growth factor for colonic epithelial cells, Gastroenterology 121 (2001) 79-90.
[35] Henson M.C., Castracane V.D., Leptin in pregnancy, Biol. Reprod. 63 (2000) 1219-1228.

[36] Henson M.C., Swan K.F., O’Neil J.S., Expression of placental leptin and leptin receptor transcripts in early pregnancy and at term, Obstet. Gynecol. 92 (1998) 1020-1028.

[37] Henson M.C., Castracane V.D., O'Neil J.S., Gimpel T., Swan K.F., Green A.E., Shi W., Serum leptin concentrations and expression of leptin transcripts in placental trophoblast with advancing baboon pregnancy, J. Clin. Endocrinol. Metab. 84 (1999) 2543-2549.

[38] Herrera E., Lasuncion M.A., Huerta L., MartinHidalgo A., Plasma leptin levels in rat mother and offspring during pregnancy and lactation, Biol. Neonate 78 (2000) 315-320.

[39] Highman T.J., Friedman J.E., Huston L.P., Wong W.W., Catalano P.M., Longitudinal changes in maternal serum leptin concentrations, body composition, and resting metabolic rate in pregnancy, Am. J. Obstet. Gynecol. 178 (1998) 1010-1015.

[40] Hoggard N., Hunter L., Duncan J.S., Williams L.M., Trayhurn P., Mercer J.G., Leptin and leptin receptor mRNA and protein expression in the murine fetus and placenta, Proc. Natl. Acad. Sci. USA 94 (1997) 11073-11078.

[41] Hoggard N., Hunter L., Lea R.G., Trayhurn P., Mercer J.G., Ontogeny of the expression of leptin and its receptor in the murine fetus and placenta, Br. J. Nutr. 83 (2000) 317-326.

[42] Holtenius K., Agenäs S., Delavaud C., Chilliard Y., Effect of dry period feed intake on plasma leptin in dairy cows, Biotech. Agro. Soc. Env. 5 (2001) 58.

[43] Houseknecht K.L., McGuire M.K., Portocarrero C.P., McGuire M.A., Beerman K., Leptin is present in human milk and is related to maternal plasma leptin concentration and adiposity, Biochem. Biophys. Res. Commun. 240 (1997) 742-747.

[44] Houseknecht K.L., Baile C.A., Matteri R.L., Spurlock M.E., The biology of leptin: a review, J. Anim. Sci. 76 (1998) 1405-1420.

[45] Howard J.K., Lord G.M., Matarese G., Vendetti S., Ghatei M.A., Ritter M.A., Lechler R.I., Bloom S.R., Leptin protects mice from starvation-induced lymphoid atrophy and increases thymic cellularity in ob/ob mice, J. Clin. Invest. 104 (1999) 1051-1059.

[46] Kadokawa H., Blache D., Yamada Y., Martin G.B., Relationship between changes in plasma concentrations of leptin before and after parturition and the timing of first post-partum ovulation in high-producing Holstein dairy cows, Reprod. Fertil. Dev. 12 (2000) 405-411.

[47] Kawai M., Yamaguchi M., Murakami T., Shima K., Murata Y., Kishi K., The placenta is not the main source of leptin production in pregnan rat: gestational profile of leptin in plasma and adipose tissues, Biochem. Biophys. Res. Commun. 240 (1997) 798-802. 
[48] Laud K., Gourdou I., Belair L., Keisler D.H Djiane J., Detection and regulation of leptin receptor mRNA in ovine mammary epithelial cells during pregnancy and lactation, FEBS Lett. 463 (1999) 194-198.

[49] Laud K., Gourdou I., Pessemesse L., Peyrat J.P., Djiane J., Identification of leptin receptors in human breast cancer: functional activity in the T47-D breast cancer cell line, Mol. Cell Endocrinol. 188 (2002) 219-229.

[50] Lauszus F.F., Schmitz O., Vestergaard H., Klebe J.G., Pedersen O., Serum leptin levels in pregnant women with type 1 diabetes mellitus, Acta Obstet. Gynecol. Scand. 80 (2001) 596-601.

[51] Lee G.H., Proenca R., Montez J.M., Carroll K.M., Darvishzadeh J.G., Lee J.I., Friedman J.M., Abnormal splicing of the leptin receptor in diabetic mice, Nature 379 (1996) 632-635.

[52] Levine J.F., Stockdale F.E., 3T3-L1 adipocytes promote the growth of mammary epithelium, Exp. Cell Res. 151 (1984) 112-122.

[53] Lewandowski K., Horn R., O'Callaghan C.J., Dunlop D., Medley G.F., O'Hare P., Brabant G., Free leptin, bound leptin, and soluble leptin receptor in normal and diabetic pregnancies, J. Clin. Endocrinol. Metab. 84 (1999) 300-306.

[54] Lewin M.J., Bado A., Gastric leptin, Microsc. Res. Tech. 53 (2001) 372-376.

[55] Liefers S.C., Veerkamp R.F., te Pas M.F.W., Delavaud C., Chilliard Y., van der Lende T., Association of leptin polymorphisms with milk yield, dry matter intake, energy balance, luteal activity and serum leptin levels during lactation in HF dairy cows, Proc. British Society of Animal Sciences, April 2002, p. 45.

[56] Lönnerdal B., Havel P.J., Serum leptin concentrations in infants: effects of diet, sex, and adiposity, Am. J. Clin. Nutr. 72 (2000) 484-489.

[57] Lord G.M., Matarese G., Howard J.K., Baker R.J., Bloom S.R., Lechler R.I., Leptin modulates the T-cell immune response and reverses starvation-induced immunosuppression, Nature 394 (1998) 897-901.

[58] Luoh S.M., Di Marco F., Levin N., Armanini M., Xie M.H., Nelson C., Bennett G.L., Williams M., Spencer S.A., Gurney A., de Sauvage F.J., Cloning and characterization of a human leptin receptor using a biologically active leptin immunoadhesin, J. Mol. Endocrinol. 18 (1997) $77-85$.

[59] Lyons W.R., Hormonal synergism in mammary growth, Proc. R. Soc. B 149 (1958) 303-325.

[60] Martinet J., Houdebine L.M., Mammary gland, mammogenesis, growths factors, lactogenesis, in: Martinet J., Houdebine L.M., Head H.H (Ed.), Biology of lactation, INRA Publ., Paris, 1999, pp. 1-27.

[61] Masuzaki H., Ogawa Y., Sagawa N., Hosoda K., Matsumoto T., Mise H., Nishimura H., Yoshimasa Y., Tanaka I., Mori T., Nakao K., Nonadipose tissue production of leptin: leptin as a novel placenta-derived hormone in humans, Nat. Med. 3 (1997) 1029-1033.

[62] Matarese G., Leptin and the immune system how nutritional status influences the immune response, Eur. Cytokine Netw. 11 (2000) 7-14.

[63] Mistry A.M., Swick A., Romsos D.R., Leptin alters metabolic rates before acquisition of its anorectic effect in developing neonatal mice, Am. J. Physiol. 277 (1999) R742-R747.

[64] Morton N.M., Emilsson V., Liu Y.L., Cawthorne M.A., Leptin action in intestinal cells, J. Biol. Chem. 273 (1998) 26194-26201.

[65] Mostyn A., Bird J.A., Clarke L., Stephenson T. Symonds M.E., Effect of postnatal age and beta(3)-adrenergic agonist (Zeneca D7114) administration on uncoupling protein-1 abundance in the lamb, Early Hum. Dev. 58 (2000) 71.

[66] Mostyn A., Keisler D.H., Webb R., Stephenson T., Symonds M.E., The role of leptin in the transition from fetus to neonate, Proc. Nutr. Soc. 60 (2001) 187-194.

[67] O’Brien S.N., Welter B.H., Price T.M., Presence of leptin in breast cell lines and breast tumors, Biochem. Biophys. Res. Commun. 259 (1999) 695-698.

[68] Okuya S., Tanabe K., Tanizawa Y., Oka Y., Leptin increases the viability of isolated rat pancreatic islets by suppressing apoptosis, Endocrinology 142 (2001) 4827-4830.

[69] O'Neil J.S., Green A.E., Edwards D.E., Swan K.F., Gimpel T., Castracane V.D., Henson M.C., Regulation of leptin and leptin receptor in baboon pregnancy: effects of advancing gestation and fetectomy, J. Clin. Endocrinol. Metab. 86 (2001) 2518-2524.

[70] Pearson P.Y., O'Connor D.M., Schwartz M.Z. Novel effect of leptin on small intestine adaptation, J. Surg. Res. 97 (2001) 192-195.

[71] Pighetti G.M., Impact of leptin on in vitro cytokine production during early and mid lactation, J. Anim. Sci. 79 Suppl. 1 (2001) 151.

[72] Plath A., Einspanier R., Gabler C., Peters F., Sinowatz F., Gospodarowicz D., Schams D. Expression and localization of members of the fibroblast growth factor family in the bovine mammary gland, J. Dairy Sci. 81 (1998) 2604-2613.

[73] Purup S., Sejrsen K., Influence of leptin on proliferation of bovine mammary epithelial cells in collagen gel culture, in: van Arendonk J.A.M., Hofer A., van der Honing Y., Madec F., Sejrsen K., Pullar D., Bodin L., Fernandez J.A., Brun E.W. (Eds.), Book of abstracts of the 51st Annual Meeting of the European Association for Animal Production, The Hague, The Netherlands 21-24 August 2000, p. 230.

[74] Resto M., O'Connor D., Leef K., Funanage V., Spear M., Locke R., Leptin levels in preterm human breast milk and infant formula, Pediatrics 108 (2001) E15. 
[75] Rosi F., Bontempo V., Capalbo R., Baldi A. Effects of rumen-protected methionine on milk yield, milk leptin and milk nitrogeneous compounds during lactation, in: Baldi A., Stelwagen K. (guest Eds.), Fifth International Workshop on the Biology of Lactation in Farm Animals, Elsevier Publ., Live. Prod. Sci. 70 (2001) 178.

[76] Rudland P.S., Twiston Davies A.C., Tsao S.W., Rat mammary preadipocytes in culture produce a trophic agent for mammary epithelia prostaglandin E2, J. Cell Physiol. 120 (1984) 364-376.

[77] Silva L.F.P., VandeHaar M.J., Role of leptin in mammary cell proliferation, S. Afr. J. Anim. Sci. 29 (1999) 300-301.

[78] Silva L.F.P., VandeHaar M.J., Weber M.S., Smith G.W., Leptin receptor expression in the bovine mammary gland and other tissues, J. Anim. Sci. 79 Suppl. 1 (2001) 225.

[79] Smith J.J., Capuco A.V., Beal W.E., Akers R.M. Association of prolactin and insulin receptors with mammogenesis and lobulo-alveolar formation in pregnant ewes, Int. J. Biochem. 21 (1989) 73-81.

[80] Smith J.L., Sheffield L.G., The production and regulation of leptin in bovine mammary epithelial cells, J. Anim. Sci. 79 Suppl. 1 (2001) 102.

[81] Smith-Kirwin S.M., O'Connor D.M., De Johnston J., Lancey E.D., Hassink S.G., Funanage V.L., Leptin expression in human mammary epithelial cells and breast milk, J. Clin. Endocrinol. Metab. 83 (1998) 1810-1813.

[82] Southern E.M., Detection of specific sequences among DNA fragments separated by gel Electrophoresis, J. Mol. Biol. 98 (1975) 503-517.

[83] Stehling O., Doring H., Ertl J., Preibisch G., Schmidt I., Leptin reduces juvenile fat stores by altering the circadian cycle of energy expenditure, Am. J. Physiol. 271 (1996) R1770-R1774.

[84] Stephenson T., Budge H., Mostyn A., Pearce S., Webb R., Symonds M., Fetal and neonata adipose maturation: a primary site of cytokine and cytokine-receptor action, Biochem. Soc Trans. 29 (2001) 80-85.

[85] Tamura T., Goldenberg R.L., Johnston K.E., Cliver S.P., Serum leptin concentrations during pregnancy and their relationship to fetal growth, Obstet. Gynecol. 91 (1998) 389-395.

[86] Tartaglia L.A., The leptin receptor, J. Biol. Chem. 272 (1997) 6093-6096.

[87] Tartaglia L.A., Dembski M., Weng X., Deng N., Culpepper J., Devos R., Richards G.J., Campfield L.A., Clark F.T., Deeds J., Muir C., Sanker S., Moriarty A., Moore, K.J., Smutko J.S., Mays G.G., Woolf E.A., Monroe C.A., Tepper R.I., Identification and expression cloning of a leptin receptor, OB-R, Cell 83 (1995) 1263-1271.
[88] Thomas L., Wallace J.M., Aitken R.P., Mercer J.G., Trayhurn P., Hoggard N., Circulating leptin during ovine pregnancy in relation to maternal nutrition, body composition and pregnancy outcome, J. Endocrinol. 169 (2001) 465-476.

[89] Tomimatsu T., Yamaguchi M., Murakami T., Ogura K., Sakata M., Mitsuda N., Kanzaki T., Kurachi H., Irahara M., Miyake A., Shima K., Aono T., Murata Y., Increase of mouse leptin production by adipose tissue after midpregnancy: gestational profile of serum leptin concentration, Biochem. Biophys. Res. Commun. 240 (1997) 213-215.

[90] Twombly G.H., Bassett M., Meisel D., Levitz M., Estrogen storage in fat, Am. J. Obstet. Gynecol. 99 (1967) 785-795.

[91] Uçar B., Kirel B., Bor O., Kilic F.S., Dogruel N., Aydogdu S.D., Tekin N., Breast milk leptin concentrations in initial and terminal milk samples: relationships to maternal and infant plasma leptin concentrations, adiposity, serum glucose, insulin, lipid and lipoprotein levels, J. Pediatr. Endocrinol. Metab. 13 (2000) 149-156.

[92] Villarroya F., Brun S., Giralt M., Camara Y., Solanes G., Iglesias R., Gene expression of leptin and uncoupling proteins: molecular endpoints of fetal development, Biochem. Soc. Trans. 29 (2001) 76-80.

[93] Wang M.Y., Zhou Y.T., Newgard C.B., Unger R.H. A novel leptin receptor isoform in rat, FEBS Lett. 392 (1996) 87-90.

[94] Whitley N.C., McFadin-Buff E.L., Buff P.R. Keisler D.H., Leptin in neonatal pigs: effects of oral versus intramuscular administration, J. Anim. Sci. 79 Suppl. 1 (2001) 429.

[95] Widjaja A., Hofmann R., Bruhn J., von zur Muhlen A., Brabant G., Free and bound leptin levels during human pregnancy, Gynecol. Endocrinol. 14 (2000) 264-269.

[96] Woodside B., Abizaid A., Walker C., Changes in leptin levels during lactation: implications for lactational hyperphagia and anovulation, Horm. Behav. 37 (2000) 353-365.

[97] Woodward T.L., Xie J.W., Haslam S.Z., The role of mammary stroma in modulating the proliferative response to ovarian hormones in the normal mammary gland, J. Mammary Gland Biol. Neoplasia 3 (1998) 117-131.

[98] Yamamoto Y., Ueta Y., Hara Y., Serino R., Nomura M., Shibuya I., Shirahata A., Yamashita H., Postnatal development of orexin/hypocretin in rats, Mol. Brain Res. 78 (2000) 108-119.

[99] Zhang Y., Proenca R., Maffei M., Barone M., Leopold L., Friedman J.M., Positional cloning of the mouse obese gene and its human homologue, Nature 372 (1994) 425-432. 